\title{
Molecular Cloning and Expression of Penicillinase Genes from Bacillus licheniformis in the Thermophile Bacillus stearothermophilus
}

\author{
By MIKIO FUJII, TADAYUKI IMANAKA AND SHUICHI AIBA* \\ Department of Fermentation Technology, Faculty of Engineering, Osaka University, \\ Yamada-oka, Suita-shi, Osaka 565, Japan
}

(Received 18 March 1982)

\begin{abstract}
By using plasmid pTB90, penicillinase genes, penP and penI, from both the wild-type and constitutive strains of Bacillus licheniformis $9945 \mathrm{~A}$ were cloned and expressed in a thermophile, Bacillus stearothermophilus. Bacillus stearothermophilus carrying the recombinant plasmid produced a large amount of penicillinase $\left[3300 \mathrm{U}\left(\mathrm{mg}^{\circ} \text { cells }\right)^{-1}\right]$ at $48^{\circ} \mathrm{C}$, whereas the amount of enzyme produced at $55^{\circ} \mathrm{C}$ and $60^{\circ} \mathrm{C}$ was reduced to $660 \mathrm{U}(\mathrm{mg} \text { cells })^{-1}$ and $39 \mathrm{U}(\mathrm{mg} \text { cells })^{-1}$, respectively. Active repressor for penicillinase functioned normally. About 10 to $20 \%$ of the total penicillinase was secreted into the culture medium by the transformant of $B$. stearothermophilus.
\end{abstract}

\section{INTRODUCTION}

The genus Bacillus represents one of the most important groups of bacteria not only for the production of commercially valuable enzymes but also for the study of the secretion mechanism of extracellular enzymes. Molecular cloning with plasmids has been well documented in some Bacillus species. However, only a few examples have been reported for the cloning of structural genes for extracellular enzymes in the genus Bacillus, i.e. the cloning of penicillinase genes of Bacillus licheniformis in Bacillus subtilis and B. licheniformis (Gray \& Chang, 1981; Imanaka et $a l ., 1981 b$ ), and the cloning of the $\alpha$-amylase gene of Bacillus amyloliquefaciens in B. subtilis (Palva et al., 1981). So far such studies have been restricted to mesophilic bacteria.

The cloning of penicillinase genes of $\boldsymbol{B}$. licheniformis in Bacillus stearothermophilus is significant with regard to examining the possibility of producing the enzyme at higher temperatures and of elucidating the difference in secretion of extracellular enzymes between mesophiles and thermophiles. The cloning of such genes would thus be of practical and academic interest.

We have established a transformation system in $B$. stearothermophilus by using a shuttle vector plasmid pTB90 between the thermophile B. stearothermophilus and the mesophile B. subtilis (Imanaka et al., 1982). The purpose of this paper is to show the expression of penicillinase genes, penP and penI, from a mesophile in a thermophilic Bacillus strain.

\section{METHODS}

Media and materials. All the media used in this work have been described by Imanaka et al. (1981 $a, b, 1982)$. The companies and laboratories, from which the antibiotics, restriction enzymes and all other reagents used here were purchased were the same as those used in previous works (Imanaka et al., 1981 $a, b, 1982$ ).

Bacterial strain and plasmids. Bacillus stearothermophilus CU21 (streptomycin resistant; Imanaka et al., 1982) was used as the host strain. pTB90 (encoding resistance to both kanamycin and tetracycline, $\mathrm{Km}^{r} \mathrm{Tc}^{r}$; Imanaka $e t$ al., 1982) was used as the vector plasmid. Penicillinase genes from both the constitutive and wild-type strains of $B$. licheniformis $9945 \mathrm{~A}$ have been cloned in Escherichia coli with pMB9 (Tcr) as vector plasmid. These recombinant plasmids are designated, pTTE11 ( $\mathrm{Tc}^{r}$ pen $P^{+}$pen 110$)$ and pTTE2 $1\left(\mathrm{Tc}^{r}\right.$ pen $P^{+}$pen $I^{+}$), respectively (Imanaka et al., $198 \mathrm{I}$ b). pen $P$ and penI are the structural gene and the repressor gene for penicillinase, respectively, and are coded on the same $E c o$ RI fragment (2.8 MDal, Imanaka et al., $1981 \mathrm{~b}$ ). The restriction endonuclease cleavage maps of these plasmids are shown in the upper row of Fig. I. 
Preparation of plasmid DNA. Plasmid DNA was prepared from B. stearothermophilus by the rapid alkaline extraction method or $\mathrm{CsCl}$-ethidium bromide equilibrium density gradient centrifugation as described previously (Imanaka et al, 1981 a, 1982). pTTE11 and pTTE21 were prepared from Escherichia coli as described elsewhere (Imanaka et al., 1981 b).

Transformation. Transformation of B. stearothermophilus protoplasts with plasmid DNA was performed as described previously (Imanaka et al., 1982). Transformants were selected on regeneration agar containing either kanamycin $\left(\mathrm{Km} ; 25 \mu \mathrm{g} \mathrm{ml}^{-1}\right.$ ) or tetracycline ( $\mathrm{Tc} ; 5 \mu \mathrm{g} \mathrm{ml}^{-1}$ ), and stored on L agar containing $\mathrm{Km}\left(5 \mu \mathrm{g} \mathrm{ml}^{-1}\right)$ or $\mathrm{Tc}\left(5 \mu \mathrm{g} \mathrm{ml} \mathrm{I}^{-1}\right)$ at $4{ }^{\circ} \mathrm{C}$.

Detection of penicillinase-positive colonies on plates. Antibiotic-resistant transformants were transferred by replica plating on $\mathrm{L}$ agar containing $0.75 \%(\mathrm{w} / \mathrm{v})$ polyvinylalcohol and the specific antibiotic $(\mathrm{Km}$ or $\mathrm{Tc})$. After colony formation at $48{ }^{\circ} \mathrm{C}$, penicillinase-positive $\left(\mathrm{PCase}^{+}\right)$colonies were detected quickly by adding an iodine solution as described by Sherratt \& Collins (1973).

Penicillinase assay. Bacillus stearothermophilus strains carrying the cloned penicillinase genes were grown at constant temperatures $\left(48,55\right.$ and $\left.60^{\circ} \mathrm{C}\right)$ in $\mathrm{LG}$ broth. $\mathrm{Km}\left(5 \mu \mathrm{g} \mathrm{ml}^{-1}\right)$ was added to the culture medium to guarantee the presence of the recombinant plasmid. Penicillinase was assayed in both the culture broth directly and in cell-free culture supernatant by the iodometric method as described previously (Imanaka et al., 1981 b). One unit of penicillinase was defined as the quantity required to hydrolyse $1 \mu \mathrm{mol}$ of penicillin $\mathrm{G} \mathrm{h}^{-1}$ at $30^{\circ} \mathrm{C}$. For the inducibility test, $2 \mu \mathrm{g} \mathrm{ml}^{-1}$ of cephalosporin $\mathrm{C}$ was used as an inducer, since $5 \mu \mathrm{g}$ cephalosporin $\mathrm{C} \mathrm{ml} \mathrm{m}^{-1}$ used for $B$. licheniformis (Imanaka et al., 1981 b) in LG broth produced bacterial lysis.

Other procedures. Procedures for digestion of plasmid DNA with restriction endonucleases, ligation of DNA and agarose gel electrophoresis are all described elsewhere (Imanaka et al., 1981 b, 1982).

\section{RESULTS}

Cloning of penicillinase genes, penP and penI, from $B$. licheniformis in $B$. stearothermophilus

Cloning of penicillinase genes was attempted in a thermophilic bacterium $B$. stearothermophilus CU21. Partially digested pTB90 DNA with EcoRI was mixed with an EcoRI digest of
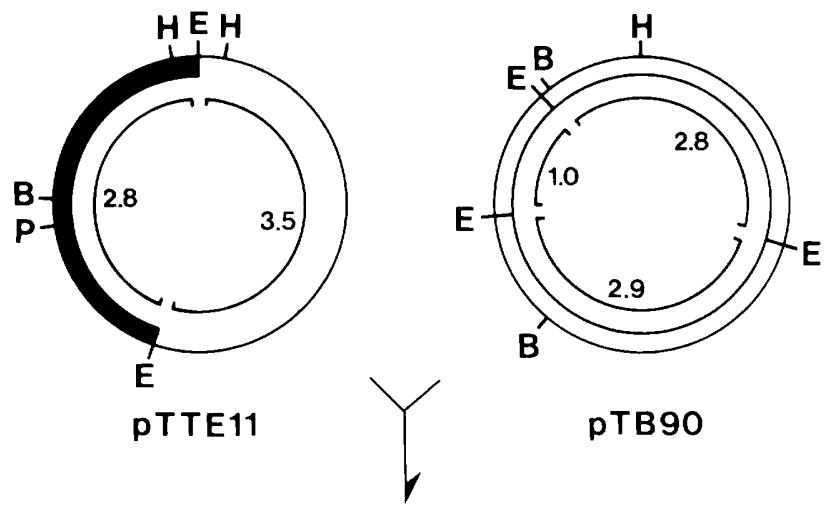

PTB90

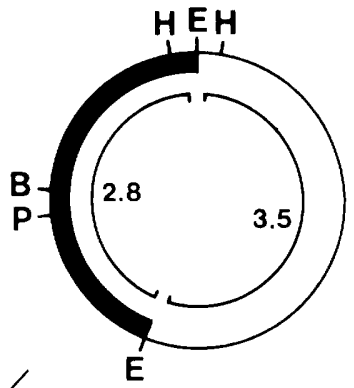

PT TE21

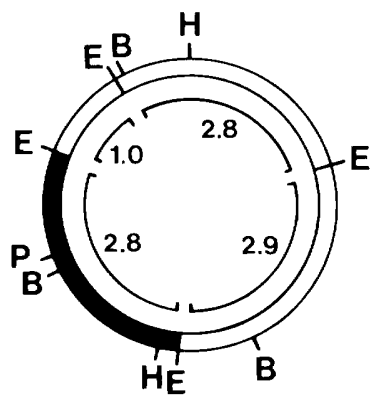

PLP11

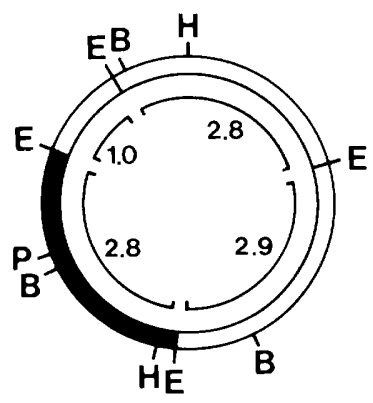

PLP21

Fig. 1. Restriction endonuclease cleavage maps of plasmids. Cleavage sites of $B g / \mathrm{II}$, EcoRI, HindIII and $P_{s t} \mathrm{I}$ are indicated by $\mathrm{B}, \mathrm{E}, \mathrm{H}$ and $\mathrm{P}$, respectively. Outer circles, $\cdots$, originated from pMB $; \square$, from pTB90; EcoRI fragment containing penicillinase genes from $B$. licheniformis. The numbers inside the inner circles indicate molecular size of EcoRI fragments in MDal. 
pTTE11 (pen $P^{+}$penI $\left.I^{-}\right)$or pTTE21 (pen $P^{+}$penI $\left.I^{+}\right)$, followed by ligation. The ligation mixtures (pTTE11 + pTB90 and pTTE21 + pTB90) were used to transform B. stearothermophilus CU21. Several $\mathrm{Km}^{\mathrm{r}} \mathrm{Tc}^{r}$ PCase $^{+}$transformants were obtained with each ligation mixture. Plasmids were isolated from these transformants and examined by agarose gel electrophoresis. The smallest recombinant plasmids obtained from the ligation mixture of pTTE11 plus pTB90 and pTTE21 plus pTB90 were designated as pLP11 and pLP21, respectively.

These plasmids were digested with several restriction endonucleases and subjected to agarose gel electrophoresis. The results obtained from these analyses (results not shown) were consistent with the restriction endonuclease cleavage maps of pLP11 and pLP21 as shown in Fig. 1.

\section{Expression of penicillinase genes in B. stearothermophilus at elevated temperatures}

Penicillinase activity was measured for the whole culture of $B$. stearothermophilus with and without recombinant plasmid carrying penicillinase genes in the absence of inducer (Table 1). No enzyme activities were detected for either B. stearothermophilus or the strain carrying only the vector plasmid pTB90. Bacillus stearothermophilus cells carrying pLP21 (pen $P^{+}$penI $I^{+}$) produced nearly the same amount of penicillinase [90 to $120 \mathrm{U}(\mathrm{mg} \text { cells })^{-1}$ ] at 48 and $55^{\circ} \mathrm{C}$, while considerably less activity was detected by cultivation at $60^{\circ} \mathrm{C}\left[17 \mathrm{U}(\mathrm{mg} \text { cells })^{-1}\right]$. On the contrary, a large amount of penicillinase $\left[3300 \mathrm{U}(\mathrm{mg} \text { cells })^{-1}\right]$ was observed for the strain harbouring pLP11 (pen $P^{+}$penI $I^{-}$). However, the enzyme activity sharply decreased with increase in temperature of cultivation. It is evident from these facts that both genes, pen $P$ and penI, were expressed in B. stearothermophilus.

As described previously (Imanaka et al., 1982), the copy number of pTB90 in $B$. stearothermophilus CU21 is amplified in the presence of Tc. The copy number of pLP11 should therefore increase, if Tc was added to the medium. Bacillus stearothermophilus CU21 carrying pLP11 was cultivated at $48^{\circ} \mathrm{C}$ in LG plus $\mathrm{Km}\left(5 \mu \mathrm{g} \mathrm{ml}^{-1}\right)$ containing 1 to $4 \mu \mathrm{g} \mathrm{Tc} \mathrm{ml}{ }^{-1}$ and penicillinase activities were measured for the culture broth (Table 1). With an increase in the amount of Tc added, penicillinase activities were enhanced. The highest penicillinase activity $\left[6000 \mathrm{U}(\mathrm{mg} \mathrm{cells})^{-1}\right]$ was detected when the bacterium was cultivated in the presence of $3 \mu \mathrm{g} \mathrm{Tc}$ $\mathrm{ml}^{-1}$, about a twofold increase of penicillinase compared with the amount found in the absence of Tc [3300 $\mathrm{U}$ (mg cells $\left.)^{-1}\right]$.

Penicillinase activity was also measured for the cell-free supernatant (Table 1). About 10 to $20 \%$ of the total penicillinase was secreted into the culture medium at $48^{\circ} \mathrm{C}$.

Table 1. Penicillinase activity of $B$. stearothermophilus

\begin{tabular}{|c|c|c|c|c|}
\hline \multirow[b]{2}{*}{ Plasmid } & \multirow[b]{2}{*}{ Antibiotic* } & \multirow{2}{*}{$\begin{array}{c}\text { Growth } \\
\text { temperature } \\
\left({ }^{\circ} \mathrm{C}\right)\end{array}$} & \multicolumn{2}{|c|}{$\begin{array}{l}\text { Penicillinase activity }{ }^{\dagger} \\
{\left[\mathrm{U}(\mathrm{mg} \text { of cells })^{-1}\right]}\end{array}$} \\
\hline & & & Total & Supernatant \\
\hline None & None & 48 & ND & - \\
\hline pТB90 & $\mathrm{Km}(5)$ & 48 & ND & - \\
\hline pLP21 & $\mathrm{Km}(5)$ & 48 & 90 & $7 \cdot 4$ \\
\hline pLP21 & $\mathrm{Km}(5)$ & 55 & 120 & - \\
\hline pLP21 & $\mathrm{Km}(5)$ & 60 & 17 & - \\
\hline pLP1 I & $\mathrm{Km}(5)$ & 48 & 3300 & 820 \\
\hline pLP11 & $\mathrm{Km}(5)$ & 55 & 610 & - \\
\hline pLP11 & $\mathrm{Km}(5)$ & 60 & 39 & - \\
\hline pLPII & $\mathrm{Km}(5)+\mathrm{Tc}(1)$ & 48 & 3700 & 510 \\
\hline pLP11 & $\mathrm{Km}(5)+\mathrm{Tc}_{\mathrm{c}}(2)$ & 48 & 4700 & 680 \\
\hline pLP11 & $\mathrm{Km}(5)+\mathrm{Tc}(3)$ & 48 & 6000 & 700 \\
\hline pLPII & $\mathrm{Km}(5)+\mathrm{Tc}_{\mathrm{c}}(4)$ & 48 & 5800 & 750 \\
\hline
\end{tabular}

-, Not tested.

ND, Not detectable $\left[0.01 \mathrm{U}(\mathrm{mg} \text { dry cell } w \mathrm{t})^{-1}\right]$.

* The numbers in parentheses indicate the concentration of the antibiotic used $\left(\mu \mathrm{g} \mathrm{ml}^{-1}\right)$.

$\uparrow$ Similar results were obtained by another series of experiments. 


\section{DISCUSSION}

We have cloned penicillinase genes, pen $P$ and penI, from a mesophile $B$. licheniformis in a thermophile $B$. stearothermophilus by using the vector plasmid pTB90. The cloned penicillinase genes could be expressed in $B$. stearothermophilus even at $60^{\circ} \mathrm{C}$. The amount of penicillinase produced by $B$. stearothermophilus (pLP11) at $48^{\circ} \mathrm{C}\left[3300 \mathrm{U}(\mathrm{mg} \text { cells) })^{-1}\right]$ was as much as that produced by the magno-constitutive strain $B$. licheniformis $\mathrm{C} 01$ at $37^{\circ} \mathrm{C}\left[3000 \mathrm{U}\left(\mathrm{mg}\right.\right.$ cells) ${ }^{-1}$; Imanaka et al., $1981 b$ ]. However, the enzyme activity that was expressed decreased with increase in temperature of cultivation. The deterioration of penicillinase expressed at higher temperatures in $B$. stearothermophilus is under further investigation but may be due to the following: (i) heat inactivation of penicillinase, (ii) degradation of penicillinase by a proteolytic enzyme(s), (iii) decline in ability of the secretion mechanism for penicillinase at higher temperatures and (iv) deterioration in gene expression (transcription and translation) of foreign (mesophilic) DNA at elevated temperatures. In addition, the fact that the reduced penicillinase activity at higher temperatures for B. stearothermophilus (pLP21) was less marked than that of the pLP11 carrier strain (Table 1), suggests the thermal inactivation of the repressor.

The mode of gene expression for penicillinase in $B$. stearothermophilus is similar to that in $B$. subtilis in the sense that active repressor functioned normally (see Table 1). Penicillinase was not induced (data not shown) presumably because of the absence of the gene for antirepressor, which might titrate the repressor (penI gene product) in the presence of inducer, on the chromosome of $B$. stearothermophilus as was suggested for B. subtilis (Imanaka et al., 1981 b).

Both $B$. licheniformis and $B$. subtilis could secrete penicillinase into the culture media (Imanaka et al., 1981 b). About 10 to $20 \%$ of the total penicillinase was secreted by $B$. stearothermophilus carrying penicillinase genes compared with $30 \%$ for $B$. subtilis (Imanaka et $a l ., 1981 b$ ). With respect to the extracellular enzyme, these results might point out that some secretion mechanisms could be shared among these Bacillus species.

\section{REFERENCES}

Gray, O. \& Chang, S. (1981). Molecular cloning and expression of Bacillus licheniformis $\beta$-lactamase gene in Escherichia coli and Bacillus subtilis. Journal of Bacteriology 145, 422-428.

IMANAKA, T., FUנII, M. \& AIBA, S. (1981 $a)$. Isolation and characterization of antibiotic resistance plasmids from thermophilic bacilli and construction of deletion plasmids. Journal of Bacteriology 146, 1091 1097.

ImanaKa, T., Tanaka, T., Tsunekawa, H. \& Aiba, S. $(1981 b)$. Cloning of the genes for penicillinase, penP and penI, of Bacillus licheniformis in some vector plasmids and their expression in Escherichia coli, Bacillus subtilis, and Bacillus licheniformis. Journal of Bacteriology 147, 776-786.
Imanaka, T., Fujil, M., Aramori, I. \& Aiba, S. (1982). Transformation of Bacillus stearothermophilus with plasmid DNA and characterization of shuttle vector plasmids between Bacillus stearothermophilus and Bacillus subtilis. Journal of Bacteriology 149, 824-830.

Palva, I., Pettersson, R. F., Kalkkinen, N., Lehtovaara, P., Sarvas, M., Söderlund, H., TAKKINEN, K. \& KäÄRIÄINEN, L. (1981). Nucleotide sequence of the promoter and $\mathrm{NH}_{2}$-terminal signal peptide region of the $\alpha$-amylase gene from Bacillus amyloliquefaciens. Gene 15, 43-51.

Sherratt, D. J. \& Collins, J. F. (1973). Analysis by transformation of the penicillinase system in Bacillus licheniformis. Journal of General Microbiology 76, 217-230. 